\title{
Evaluation of Solanum species and eggplant cultivated varieties for bacterial wilt resistance
}

\author{
T.H. Singh ${ }^{1 *}$, D.C. Lakshmana Reddy ${ }^{2}$, C. Anand Reddy ${ }^{1}$, A.T. Sadashiva ${ }^{1}$ \\ P. Pandyaraj ${ }^{1}$ and Y.B. Manoj ${ }^{1}$ \\ Division of Vegetable crops, Indian Institute of Horticultural Research (IIHR), \\ Hessaraghatta Lake Post, Bengaluru - 560 089, India \\ 1Division of Vegetable crops, Indian Institute of Horticultural Research (ICAR-IIHR), Bengaluru, India \\ 2Division of Biotechnology, Indian Institute of Horticultural Research (ICAR-IIHR), Bengaluru, India \\ *Email : Singh.HT@icar.gov.in
}

\begin{abstract}
Bacterial wilt caused by Ralstonia solanacearum is one of the major diseases in Solanum species including cultivated Eggplant (Solanum melongena L.). Bacterial wilt (BW) disease management in eggplant is difficult due to high survival rate of pathogen in soil and chemical application is not eco-friendly. The best way to avoid bacterial wilt in eggplant is using disease-resistant varieties. However, only a limited number of bacterial wilt resistant varieties are available and, there is a necessity to identify and/or develop new resistant varieties. In the current study, wild Solanum species, and eggplant cultivated varieties were evaluated against Ralstonia solanacearum, and disease incidence was recorded. The cultivated varieties IIHR-108, Pusa Purple Long and Rampur Local were identified as susceptible, whereas, IIHR-7 and CARI-1 were identified as resistant to bacterial wilt. These resistant wild and cultivated varieties can be used as a root-stock in bacterial wilt disease resistant breeding programmes.
\end{abstract}

Keywords: Wild Solanum species, Eggplant, Ralstonia solanacearum, Disease scoring, Grafting

\section{INTRODUCTION}

Eggplant (Solanum melongena $\mathrm{L}$.) $(2 \mathrm{n}=24)$ is one of the most popular Solanaceous vegetable crop cultivated globally. Asia is the major producer (93\%) of eggplant (FAO, 2016). It is originated from India and South China (Daunay and Hazra, 2012). Eggplant is generally cultivated in open fields with hot and humid conditions. Eggplant is susceptible to numerous diseases viz., bacterial wilt; fusarium wilt; verticillium wilt, early blight, leaf spot, potato virus-Y (PVY), tobacco ring spot virus, tomato spotted wilt virus (TSWV), phytoplasma, and root-knot nematode. Duo to these diseases, quality and quantity of eggplant production is adversely affected.

Eggplant bacterial wilt (Ralstonia solanacearum) is a major concern in India. The pathogen is race specific and has five different races. Ralstonia solanacearum strains are divided into five different biovars based on the biochemical analysis. In India, eggplant bacterial wilt is mainly caused by Race 1 and Biovar 3 (Gopalakrishnan et al., 2005). The pathogen (Ralstonia solanacearum) can survive in soil upto ten years without any host plant and have the ability to colonize in non-host plants including a vast range of symptomless weeds (Gopalakrishnan et.al., 2014). The pathogen enters into the plants through wounds or secondary root initiation points leading to pathogen colonization in the vascular parenchyma and cell wall breakage (Ramesh, 2008). The initial wilt symptoms are leaf drooping, followed by full-plant wilting and vascular discoloration. When cut ends of wilted plant placed in water, milky white ooze out can be observed. There are different methods of artificial inoculation/ screening of bacterial wilt like root cut inoculation, leaf or stem pricking and natural field infestation (Ramesh, 2008). These pathogenic spores remain viable and active in the soil for several years making the disease control almost impossible through any means of chemical treatments especially in the regions 
where repeated eggplant cultivation is taken up. Many of the commercial varieties/hybrids are highly susceptible to bacterial wilt. Chemical management often leads to the presence of chemical residues in the fruits, thus, raises the concern of food safety. The most economical way of bacterial wilt control is to develop bacterial wilt resistant varieties/hybrids. Recently, grafting strategy using resistant root-stock has been proposed for soil-borne pathogens like bacterial wilt, and it will help in bacterial wilt resistant varieties/hybrids development with the different genetic backgrounds. Hence, identification of a bacterial wilt root-stock will be of higher use and any preferable variety/hybrid can be grafted on it. Here, we evaluated wild solanum species and cultivated varieties for bacterial wilt resistance through artificial
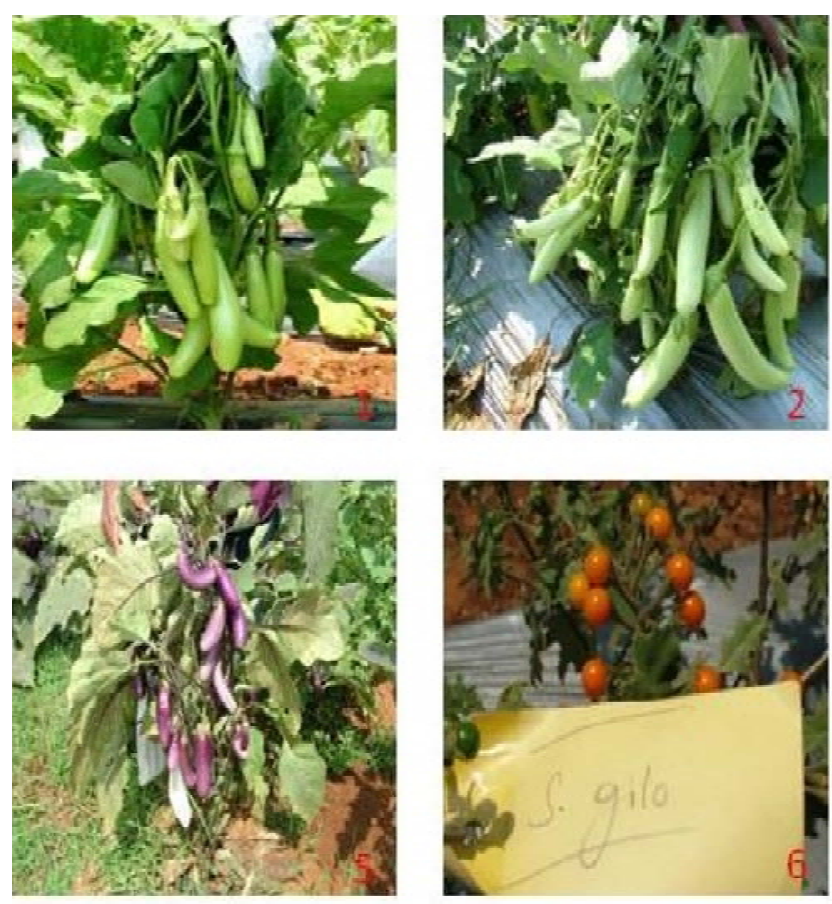

inoculation, and these can be used as root-stock in grafting.

\section{MATERIALS AND METHODS}

\section{Plant Material and Phenotypic Characters}

In this study, five eggplant cultivated varieties viz., IIHR-7 (IC395334), IIHR-662 (CARI-1, IC0585684), IIHR-108 (Arka Kusumakar), IIHR-663 (Rampur Local), and seven wild species viz., Solanum gilo (RS-3), Solanum indicum (RS-4), Solanum viarum (RS-6), Solanum aethiopicum (RS-7), Solanum mammosum (RS-8), and Solanum torvum (RS-9 and RS-9a) were used for bacterial wilt screening (Fig.1). These germplasm accessions were maintained at Indian Institute of Horticultural Research, Bengaluru.
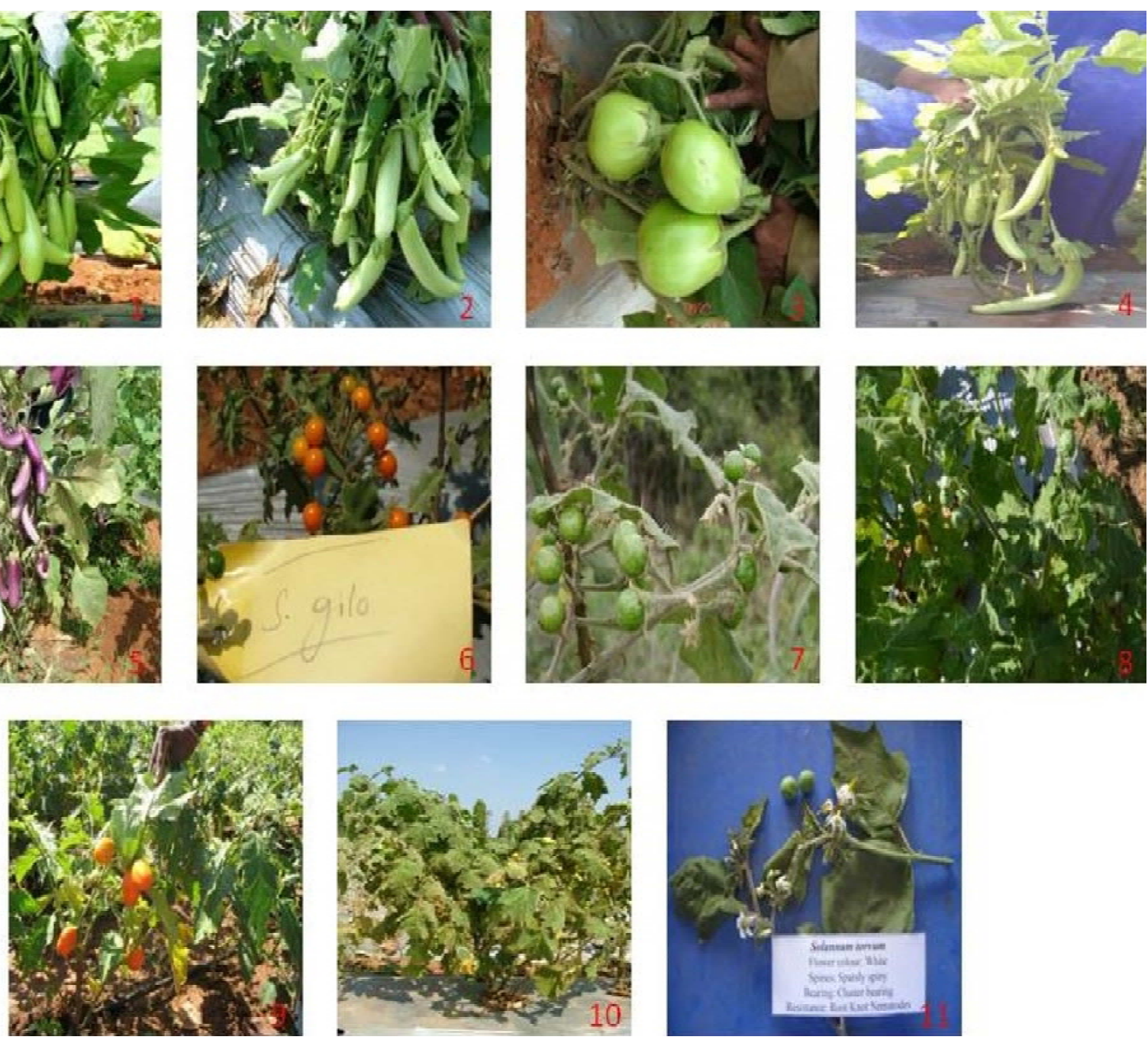

Fig. 1. Eggplant cultivated varieties [IIHR-7 (IC395334), IIHR-662 (CARI-1, IC0585684), IIHR-108 (Arka Kusumakar), IIHR663 (Rampur Local)] and seven wild species [Solanum gilo, S. indicum, S. viarum, S. aethiopicum, S. mammosum, and S. torvum used for bacterial wilt screening. 
Evaluation of eggplant for bacterial wilt resistance

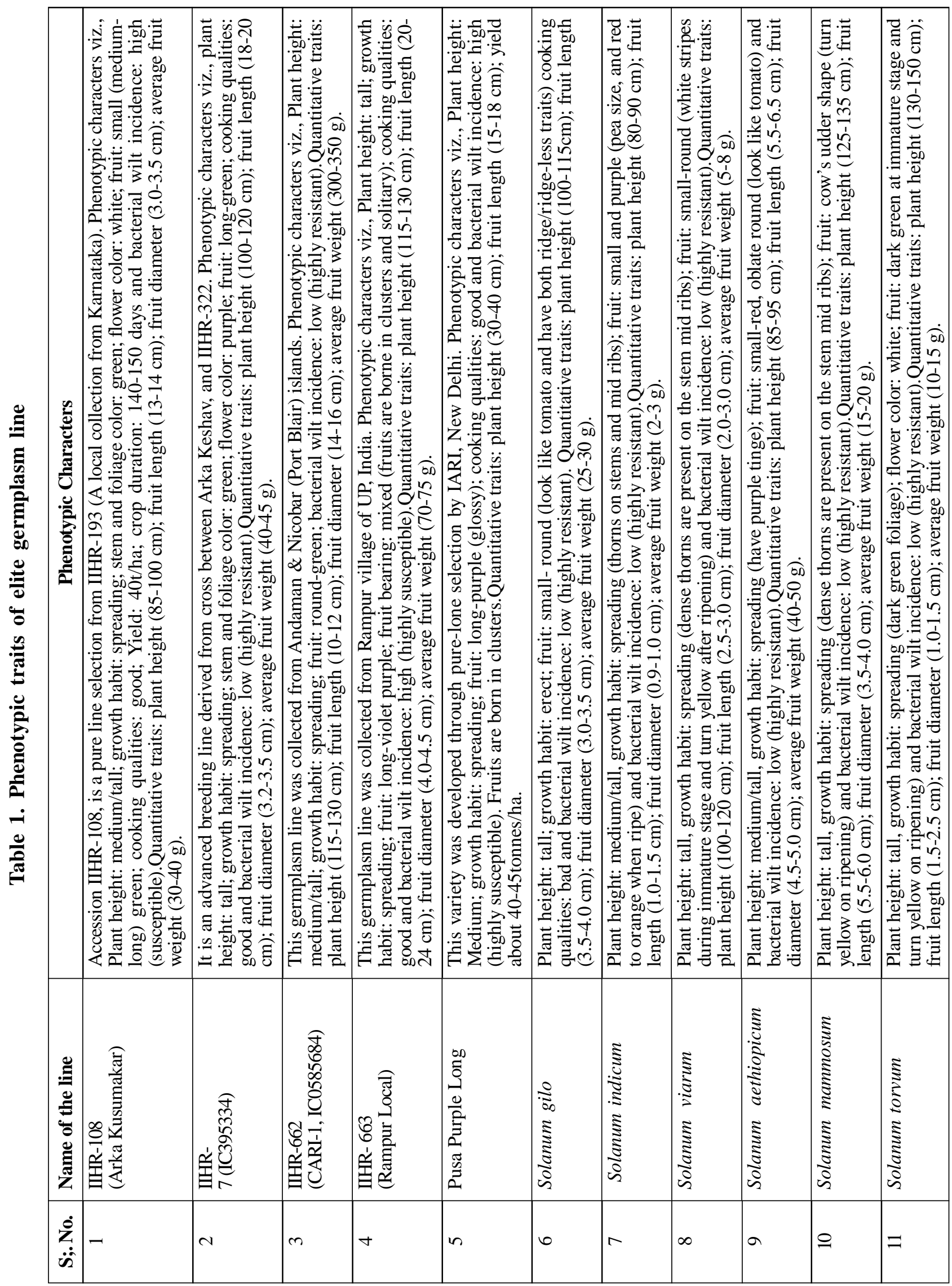


Basic information of Solanum species and eggplant varieties were described in Table 1.

\section{Artificial Screening of Bacterial Wilt}

$R$. solanacearum inoculum was prepared according to Urquhart et al. (1998) from bacterial wilted eggplants. The bacterium colonies were collected from wilted plant using ooze out test, and streaked on Triphenyl Tetrozolium Chloride (TZC or TTC) plate
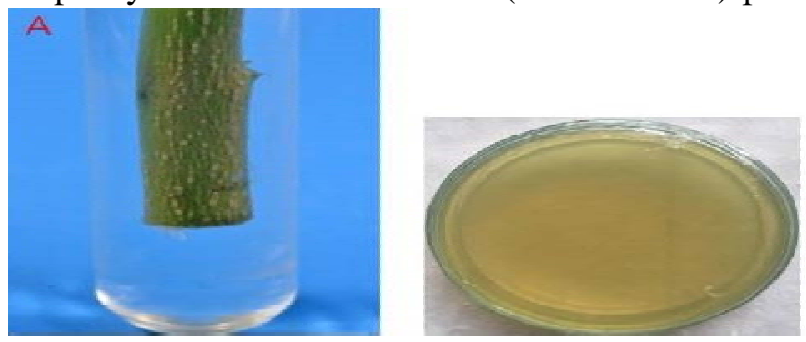

(Fig. 2). The plates were incubated at $28^{\circ} \mathrm{C}-30^{\circ} \mathrm{C}$ for 48 hours, and the TZC plates were checked for development of avirulent and virulent colonies. The separated virulent colonies were selected and suspended in sterile distilled water. The concentration of inoculum was recorded using a spectrophotometer and stored at $4^{\circ} \mathrm{C}$ for further use. Soil drenching method was used for inoculating the 25 days seedlings with $R$. solanacearum suspension, with concentration

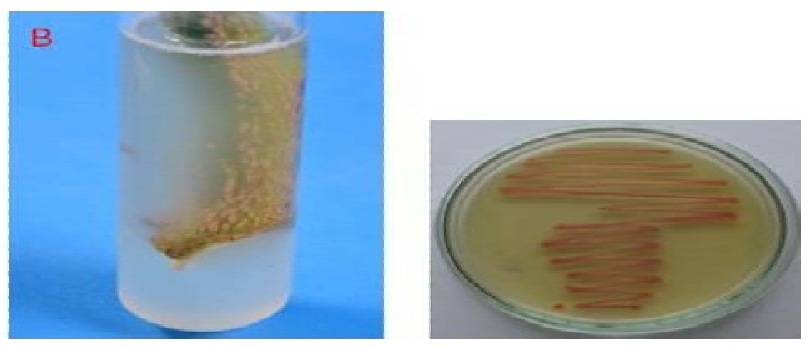

Figure 2. Ooze out test and $R$. Solanacearum virulence identification in TZC plate.

of $1.0 \times 10^{8} \mathrm{CFU} / \mathrm{ml}(\mathrm{OD} 600 \mathrm{~nm}=0.3)($ Rashmi et al., 2012).

\section{A) Resistant B) Susceptible}

\section{Observation and Bacterial Wilt Disease Screening}

According to Hussain et al. (2005), bacterial wilt symptoms and total number of wilted plants per germplasm/variety were recorded on a 0-5 scale, with minor modifications. Based on the percentage of wilted plants, accessions were categorized as highly resistant to highly susceptible.

\section{Disease scoring scale}

\begin{tabular}{|c|c|c|}
\hline S.No. & $\begin{array}{l}\text { Percentage of disease } \\
\text { Incidence }(\%)\end{array}$ & Scale $(0-5)$ \\
\hline 1 & No wilt symptom $(0 \%)$ & $\begin{array}{l}\text { Highly Resistant } \\
(\mathrm{HR})(0)\end{array}$ \\
\hline 2 & $1-10 \%$ wilted plants & Resistant (R) (1) \\
\hline 3 & $11-20 \%$ wilted plants & $\begin{array}{l}\text { Moderately Resistant } \\
(\mathrm{MR})(2)\end{array}$ \\
\hline 4 & $21-30 \%$ wilted plant & $\begin{array}{l}\text { Moderately Susceptible } \\
\text { (MS) (3) }\end{array}$ \\
\hline 5 & $31-40 \%$ wilted plants & Susceptible (S) (4) \\
\hline 6 & $>40 \%$ wilted plants & $\begin{array}{l}\text { Highly Susceptible } \\
\text { (HS) (5) }\end{array}$ \\
\hline
\end{tabular}

\section{RESULTS AND DISCUSSION}

Ralstonia solanacearum race 1 Biovar 3 is more devastating and causes a severe problem in eggplant cultivation mainly in hot $\&$ humid areas like India
(Markose, 1996). Controlling the bacterial wilt disease is practically not possible with the help of chemicals, and hence growing the resistant variety/hybrid is the best approach. In the breeding or grafting, identification of best-durable resistant root-stock is the first step. In various studies, high level of Ralstonia solanacearum resistance is reported in IIHR-7, CARI-1 and wild Solanum species Solanum torvum, LS 174, Solanum sisymbriifolium, Solanum viarum, Solanum mammosum, Solanum nigrum, Solanum maroniense and Solanum stramonifolium (Mochizuki and Yamakawa, 1979, Gousset et al., 2005; Reddy et al., 2015; Bainsla et al., 2016). Eggplant cultivated varieties and wild Solanum species were artificially inoculated with $R$. solanacearum inoculum (Concentration $\sim 1.0 \times 10^{8} \mathrm{cfu} / \mathrm{ml}$ ). After 25-35 days post-inoculation period, wilt incidence was observed on IIHR-108, Rampur Local and Pusa Purple Long. Up to 7-8 weeks, no wilting symptoms were observed on IIHR-7, CARI-1 and all wild Solanum species.

In the present study, susceptible check variety IIHR108 has shown $\sim 100 \%$ bacterial wilt incidence on artificial inoculation. In the test accessions, bacterial wilt incidence ranged from 0 to $99.33 \%$. In general, the resistance level of eggplant cultivated varieties to bacterial wilt in is limited (Bhavana and Singh, 2016). Resistant source from cultivated eggplant accessions will be highly useful in breeding due to their advantage in crossing, and no negative effects of fruits will hinder the breeding. Among the cultivable eggplant accessions, IIHR-7 (IC-395334) and IHR-662 


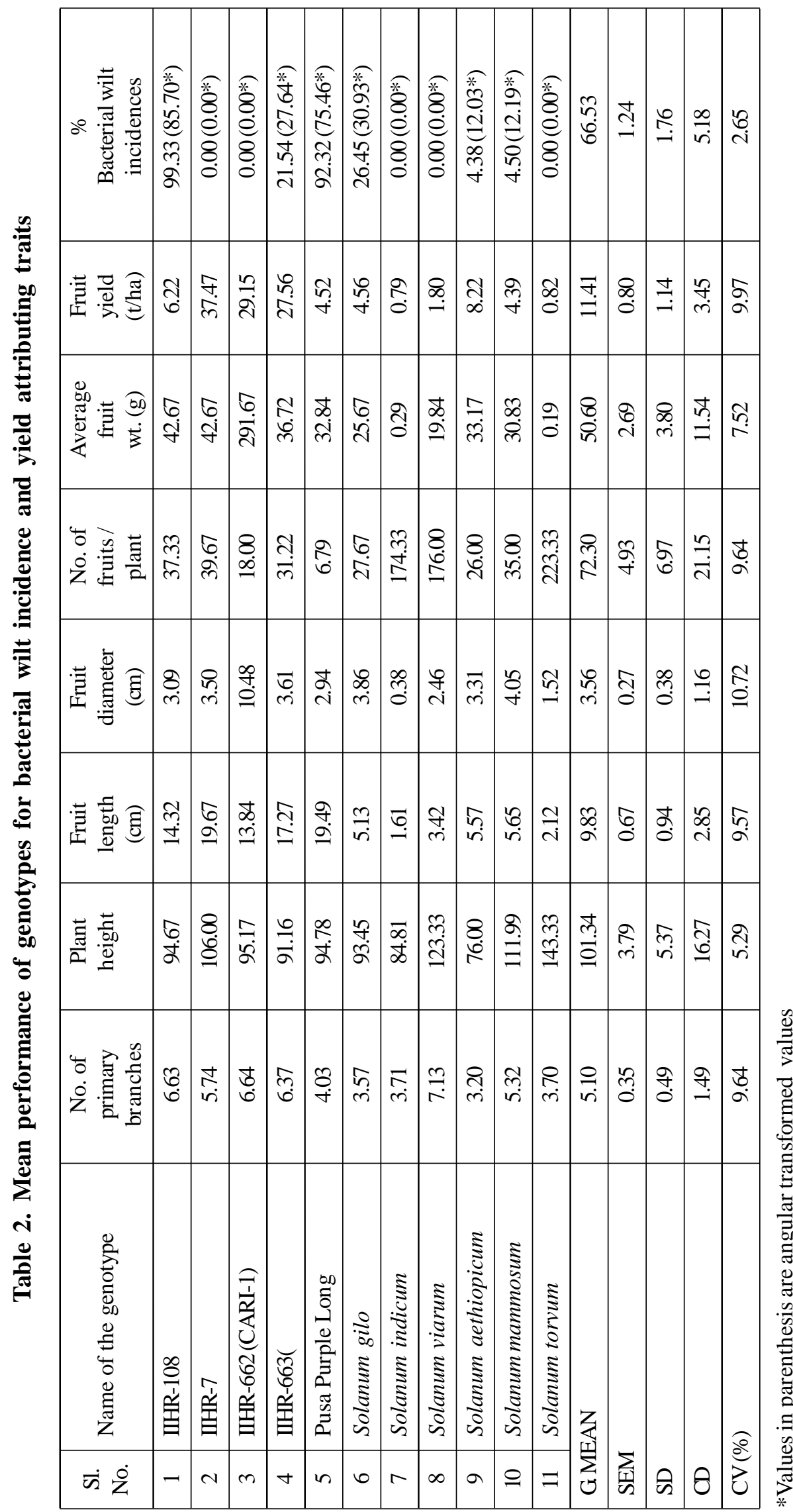


(CARI-1) were found to have high resistance with no incidence of bacterial wilt.

Among the wild species, bacterial wilt incidence ranged from 0 (Solanum torvum, Solanum viarum, and Solanum indicum) to $26.45 \%$ (Solanum gilo). Wild species are hardy in nature, and will have the special advantage of strong root system for combating other abiotic stresses. These wild species cannot be used in breeding programme easily because of negative fruit traits. However, these can be used as a root-stock for eggplant and tomato cultivation in bacterial wilt prone areas. These wild species can be effectively used for grafting the commercial varieties and hybrids of eggplant and tomato. Gopalakrishnan et al. (2005) identified high phenolic content, and some special root cortical cells in bacterial wilt resistant cultivar root system, and are thought to be responsible for controlling of R. solanacearum spreading and multiplication. Already, the success of using Solanum torvum in grafting eggplant for bacterial wilt and yield advantage has been proved. The same can be used for tomato and other Solanum cultivation. Solanum torvum have graft advantages and compatibilities with cultivated eggplant, hence, it can be effectively used in grafting programs of bacterial wilt resistant eggplant varieties/hybrids (Ashok et al., 2017). Ashok et al. (2017) reported Solanum torvum resistance with $5.7 \%$ susceptibility, whereas, in our study it was found highly resistant with no incidence. This variation in level of resistance may be due to the variability in the Solanum torvum accessions or difference in Ralstonia solanacearum races.

\section{ACKNOWLEDGEMENT}

Authors are thankful to the Director, Indian Institute of Horticultural Research (ICAR-IIHR), Bengaluru, India for providing research facilities.

\section{REFERENCES}

Ashok, K.B., Raja, P., Pandey, A.K. and Ranindro, P. 2017. Evaluation of Wilt Resistance of Wild Solanum Species through Grafting in Brinjal. Int. J. Curr. Microbiol. App. Sci., 6(9): 3464-3469.

Bainsla, N.K., Singh, S., Singh, P.K., Kumar, K., Singh, A.K. and Gautam, R.K. 2016. Genetic Behaviour of Bacterial Wilt Resistance in Brinjal (Solanum melongena L.) in Tropics of Andaman and Nicobar Islands of India. American Journal of Plant Sciences, 7: 333338.

Bhavana, P. and Singh, A.K. 2016. Biodiversity in Brinjal Germplasm against Resistance to Bacterial Wilt. Bangladesh Journal of Botany, 45(3): 737-739.

Daunay, M.C. and Hazra, P. 2012. Eggplant, In: Handbook of Vegetables, (Eds. Peter, K.V. and Hazra, P.), STUDIUM PRESS LLC, Texas, USA, 257-322.

Food and Agriculture Organisation (FAO). 2016. http://www.fao.org

Gopalakrishnan, C., Singh, T.H. and Rashmi B. Artal. 2014. Evaluation of eggplant accessions for resistance to bacterial wilt caused by Ralstonia solanacearum (E.F. Smith). J. Hortl. Sci., 9(2): 202-205.

Gopalakrishnan, T. R., Singh, P.K., Sheela, K.B., Shankar, M.A., Kutty, P.C.J. and Peter, K. V. 2005. Development of bacterial wilt resistant varieties and basis of resistance in eggplant (Solanum melongena L.). In: Bacterial Wilt: The Disease and the Ralstonia solanacearum Species Complex. C. Allen, P. Prior, and A. C. Hayward, eds. APS Press, St. Paul, MN. pp 293-300.

Gousset, C., Collonnier, C., Mulya, K., Mariska, I., Rotino, G.L., Besse, P., Servaes, A. and Sihachakr, D. 2005. Solanum torvum, as a useful source of resistance against bacterial and fungal diseases for improvement of eggplant (S. melongena L.). Plant Science, 168(2): 319-327.

Hussain, M.Z., Rahman, M.A. and Bashar, M.A. 2005. Screening of brinjal accessions for bacterial wilt caused by Ralstonia solanacearum. Bangladesh J. Botany, 34(1): 53-58.

Markose, B.L. 1996. Genetic and biochemical bases of resistance to bacterial wilt in chilli (Doctoral dissertation), Kerala Agricultural University, Thrissur, Kerala. 
Mochizuki, H. and Yamakawa, K. 1979. Resistance of selected eggplant cultivars and related wild Solanum species to bacterial wilt (Pseudomonas solanacearum). Yasai Shikenjo hokoku. Bulletin of the Vegetable and Ornamental Crops Research Station. Series A.

Ramesh, R. 2008. Bacterial wilt in brinjal and its management. Technical Bulletin No: 10, ICAR Research Complex for Goa (Indian Council of Agricultural Research), Ela, Old Goa- 403 402, Goa, India.

Rashmi, B.A., Gopalakrishnan, C. and Thippeswamy, B. 2012. An efficient inoculation method to screen tomato, brinjal and chilli entries for bacterial wilt resistance. Pest Mgt. Hortl. Ecosystems, 18: 70-73.
Reddy, A.C., Venkat, S., Singh, T.H., Aswath, C., Reddy, K.M. and Reddy, D.L. 2015. Isolation, characterization and evolution of NBS-LRR encoding disease-resistance gene analogs in eggplant against bacterial wilt. European Journal of Plant Pathology, 143(3): 417-426.

Urquhart, L., Mienie, N.J.J. and Steyn, P.L. 1998. The effect of temperature, storage period and inoculum concentration on symptom development and survival of Ralstonia solanacearum in inoculated tubers. In: Bacterial wilt disease, Springer, Berlin. pp. 351-357.

(MS Received 12 May 2018, Revised 14 May 2019, Accepted 24 June 2019) 